\title{
Updated Techniques for Estimating Monthly Streamflow-Duration Characteristics at Ungaged and Partial-Record Sites in Central Nevada
}

Open-File Report 02-168

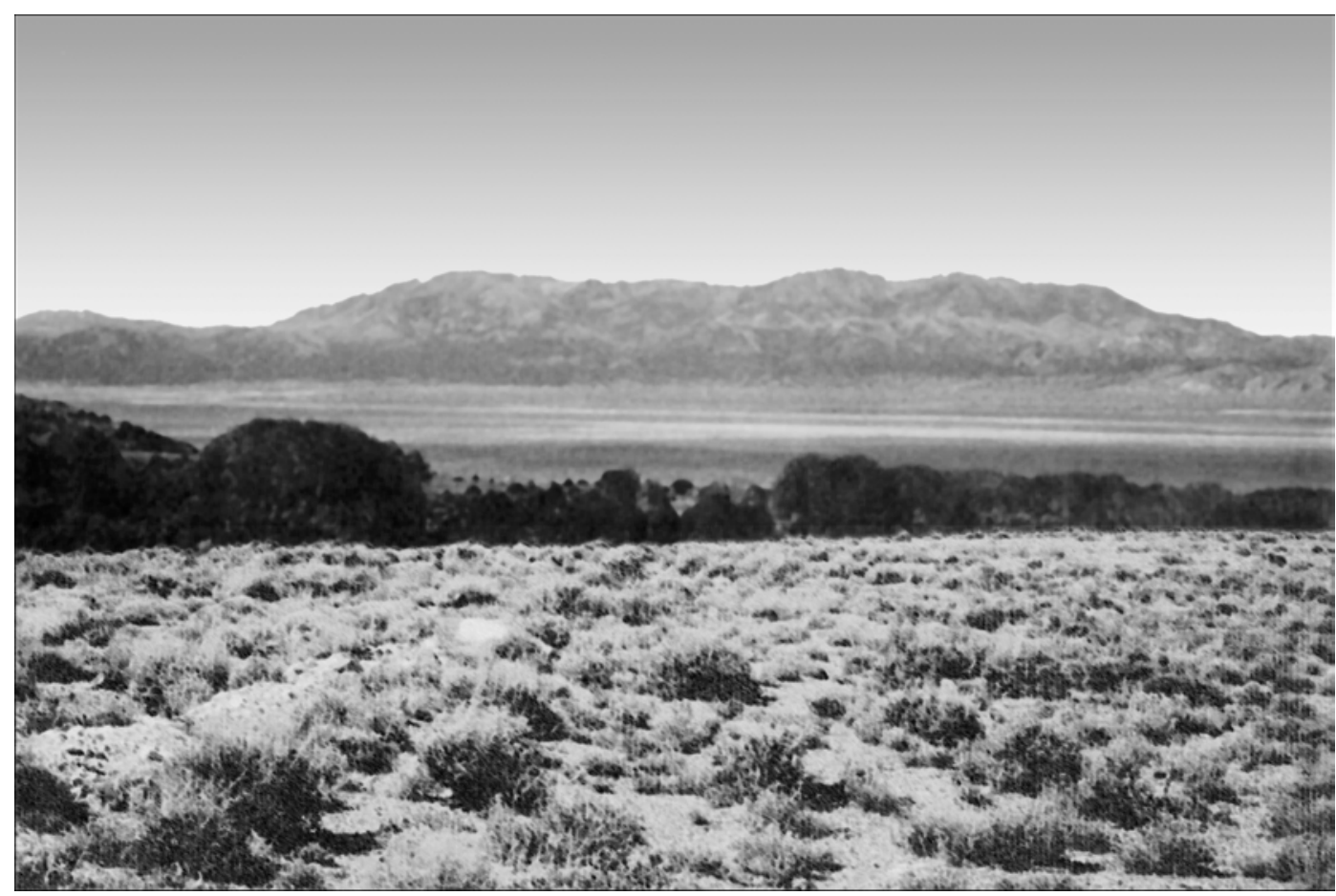

Prepared in cooperation with the

U.S. DEPARTMENT OF AGRICULTURE,

FOREST SERVICE,

TOIYABE NATIONAL FOREST

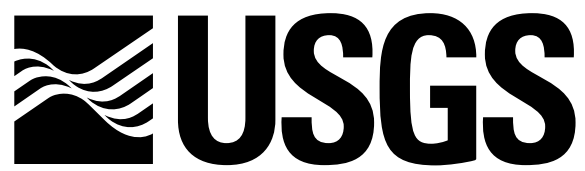

science for a changing world 
Cover photograph: Westward view of Toquima Range from east side of Monitor Valley in September 1996. Four streams discussed in this report drain eastward from the Toquima Range (see fig. 1). Photograph by John Potyondy, U.S. Forest Service. 


\section{Updated Techniques for Estimating Monthly Streamflow-Duration Characteristics at Ungaged and Partial-Record Sites in Central Nevada}

By Glen W. Hess

U.S. GEOLOGICAL SURVEY

Open-File Report 02-168

Prepared in cooperation with the

U.S. DEPARTMENT OF AGRICULTURE, FOREST SERVICE,

TOIYABE NATIONAL FOREST 


\title{
U.S. DEPARTMENT OF THE INTERIOR GALE A. NORTON, Secretary
}

\author{
U.S. GEOLOGICAL SURVEY \\ CHARLES G. GROAT, Director
}

Any use of trade names in this publication is for descriptive purposes

only and does not constitute endorsement by the U.S. Government

For additional information contact:

District Chief

U.S. Geological Survey

333 West Nye Lane, Room 203

Carson City, NV 89706-0866

email: GS-W-NVpublic-info@usgs.gov

URL: http://nevada.usgs.gov
Copies of this report can be purchased from:

U.S. Geological Survey Information Services

Building 810

Box 25286, Federal Center

Denver, CO 80225-0286 


\section{CONTENTS}

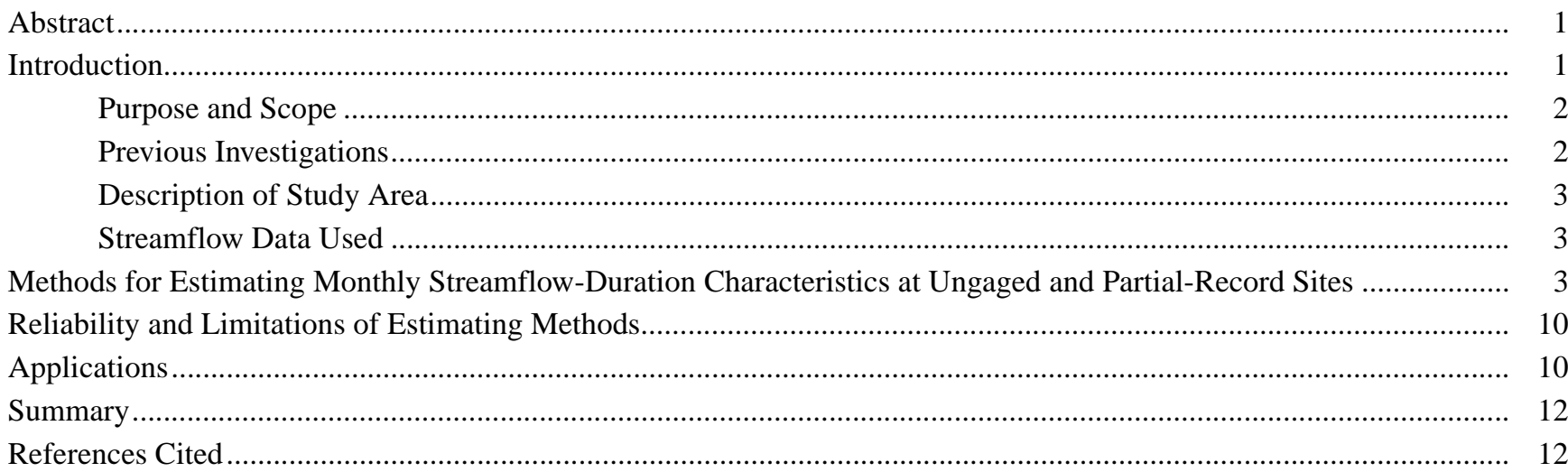

\section{FIGURES}

1. Map showing location of streamflow site and station number in central Nevada..............................................

2. Graph showing probability of streamflow-duration data from the index station, Mosquito Creek near Belmont.

\section{TABLES}

1. Mean monthly streamflow of drainage basins in central Nevada

2. Mean monthly streamflow determined at concurrent partial-record sites in central Nevada, water years 1997-2000.....

3. Monthly streamflow duration characteristics of streams at continuous-record sites in central Nevada ................. 6

4. Selected physical and climatic characteristics of selected drainage basins in central Nevada ............................. 6

5. Equations derived from basin-characteristics method for estimating monthly streamflow-duration characteristics for all months at ungaged sites in central Nevada...

6. Equations derived from basin-characteristics method for estimating monthly streamflow-duration characteristics for individual months at ungaged sites in central Nevada.

7. Equations derived from concurrent-measurement method for estimating monthly streamflow for all months at partial-record sites in central Nevada using streamflow at nearby gaging stations.

\section{CONVERSION FACTORS AND VERTICAL DATUM}

\begin{tabular}{rll}
\hline Multiply & By & To obtain \\
\hline foot (ft) & 0.3048 & meter \\
inch (in.) & 25.4 & millimeter \\
mile (mi) & 1.609 & kilometer \\
square mile $\left(\mathrm{mi}^{2}\right)$ & 2.590 & square kilometer \\
cubic foot per second $\left(\mathrm{ft}^{3} / \mathrm{s}\right)$ & 0.02832 & cubic meter per second \\
\hline
\end{tabular}

Sea level: In this report, "sea level” refers to the National Geodetic Vertical Datum of 1929 (NGVD of 1929, formerly called "Sea-Level Datum of 1929"), which is derived from a general adjustment of the first-order leveling networks of the United States and Canada. 
This page left blank for duplexing purposes. 


\title{
Updated Techniques for Estimating Monthly Streamflow- Duration Characteristics at Ungaged and Partial-Record Sites in Central Nevada
}

\author{
By Glen W. Hess
}

\begin{abstract}
Techniques for estimating monthly streamflow-duration characteristics at ungaged and partial-record sites in central Nevada have been updated. These techniques were developed using streamflow records at six continuous-record sites, basin physical and climatic characteristics, and concurrent streamflow measurements at four partial-record sites.
\end{abstract}

Two methods, the basin-characteristic method and the concurrent-measurement method, were developed to provide estimating techniques for selected streamflow characteristics at ungaged and partial-record sites in central Nevada. In the first method, logarithmic-regression analyses were used to relate monthly mean streamflows (from all months and by month) from continuous-record gaging sites of various percent exceedence levels or monthly mean streamflows (by month) to selected basin physical and climatic variables at ungaged sites. Analyses indicate that the total drainage area and percent of drainage area at altitudes greater than 10,000 feet are the most significant variables. For the equations developed from all months of monthly mean streamflow, the coefficient of determination averaged 0.84 and the standard error of estimate of the relations for the ungaged sites averaged 72 percent. For the equations derived from monthly means by month, the coefficient of determination averaged 0.72 and the standard error of estimate of the relations averaged 78 percent. If standard errors are compared, the relations developed in this study appear generally to be less accurate than those developed in a previous study. However, the new relations are based on additional data and the slight increase in error may be due to the wider range of streamflow for a longer period of record, 1995-2000.

In the second method, streamflow measurements at partial-record sites were correlated with concurrent streamflows at nearby gaged sites by the use of linear-regression techniques. Statistical measures of results using the second method typically indicated greater accuracy than for the first method. However, to make estimates for individual months, the concurrent-measurement method requires several years additional streamflow data at more partial-record sites. Thus, exceedence values for individual months are not yet available due to the low number of concurrent-streamflowmeasurement data available. Reliability, limitations, and applications of both estimating methods are described herein.

\section{INTRODUCTION}

Effective management of surface-water resources requires accurate information on the magnitude and variability of streamflow. Monthly mean flow, a statistical measure of these important properties, is of particular interest to fish and wildlife managers, water rights administrators, and other land- and water-use planners. 
In central Nevada, where precipitation is light and related streamflow is intermittent, flow data are collected non-continuously and at widely spaced sites. As a result, calculation of accurate monthly streamflowduration characteristics for streams in the area requires methods for regionalizing data from ungaged and partial-record sites.

Beginning in 1996, a need for this type of information for upland streams in central Nevada was identified and an investigation was undertaken by the U.S. Geological Survey (USGS) in cooperation with the U.S. Department of Agriculture, Forest Service (USFS), Toiyabe National Forest. An initial study was done by Hess and Bohman (1996) to determine methods for estimating monthly streamflow. Since then, an additional 4 years (1997-2000) of streamflow data have been collected. This report is a summary of the additional data collected and methods for estimating monthly streamflow-duration characteristics that have been updated with the additional data.

\section{Purpose and Scope}

This report (1) describes the data used to estimate streamflow, (2) describes two techniques for estimating monthly streamflow-duration characteristics at ungaged and partial-record sites in central Nevada, (3) discusses the reliability and limitations of those techniques, and (4) discusses applications of the estimating methods.

\section{Previous Investigations}

Methods of regionalizing selected streamflow characteristics and evaluating the reliability of each under various hydrologic conditions were described in Riggs (1972, 1973). In addition, Riggs (1973) provided examples of regionalizing streamflow characteristics for high and low flows.

Moore (1968) developed two methods for estimating mean annual runoff in ungaged semiarid areas that are applicable to either perennial or ephemeral streams. The first method, based on streamflow records, relates annual runoff to altitude for a region. The second method relates annual runoff to channel width and depth.

Maurer (1986) developed regression equations for estimating streamflow at seven tributaries of the Carson River in Carson Valley based on data from an index gaging station and concurrent-streamflow measurements (U.S. Geological Survey, 1981-83). Later, Hess (1999) updated the equations developed by Maurer (1986) with additional concurrent-measurement data expanding the database by six additional tributaries in the Carson Valley area.

Parrett and Cartier (1990) developed three methods for estimating monthly mean streamflow and various points on the daily mean streamflow-duration curve for each month, which are applicable to western Montana basins. The first method is based on multiple regression equations relating the monthly streamflow characteristics to various basin physical and climatic variables. The second method is based on regression equations relating the monthly streamflow characteristics to channel width. The third method requires monthly streamflow measurements made concurrently at the partial-record sites of interest with nearby measurements made at hydrologically similar gaged sites. This concurrent-measurement method is more reliable than the other methods for all months and nearly all monthly streamflow characteristics.

Myers and Swanson (1996) extended the record of monthly streamflows at a gaging station in northwestern Nevada using multiple-regression techniques. The purpose of these estimates was to aid in the comparison of different range management plans in the recovery of two overgrazed riparian habitats.

Hess and Bohman (1996) developed techniques for estimating monthly mean streamflow at gaged sites and monthly streamflow-duration characteristics at ungaged sites in central Nevada. Streamflow records at six gaged sites for the period 1951-95 and basin physical and climatic characteristics were used to determine equations for each month and for the entire period of record. Analyses indicated that the drainage area and percent of drainage area at altitudes greater than 10,000 $\mathrm{ft}$ were the most significant variables in those equations. Reliability and limitations of the estimating methods were described.

Using a similar analysis, Hess (2002) developed techniques for estimating monthly streamflow-duration characteristics for tributary inflows to the Middle Humboldt River. Relating drainage area and latitude to gaging station streamflow records and regression equations were developed. These equations were based on streamflow records at 33 gaging stations in northern Nevada for water years 1944-99 and were applicable 
only to that area. A water year is the 12-month period October 1 through September 30. Thus, the year ending September 30, 1999, is called the "1999 water year."

\section{Description of Study Area}

The study area is in northern Nye County, and parts of southern Lander and Eureka Counties, Nev. Termed "central Nevada" for the purposes of this report, the study area is composed largely of northsouth trending mountain ranges separated by long narrow valleys (fig. 1). The study area includes basins above about 6,000 ft in the Shoshone Mountains, and the Toiyabe, Toquima, Monitor, and Hot Creek Ranges. Altitudes for the basins studied in this investigation ranged from about 6,400 to $12,000 \mathrm{ft}$ above sea level. U.S. Highway 50 bounds the study on the north; the Shoshone Mountains and Hot Creek Range form the western and eastern boundaries of the study area, respectively. The study area generally is rugged and sparsely forested. Methods discussed in this report are not applicable to the flatter valley floors, which are mostly open range but may be used for grazing or limited agriculture.

Annual precipitation in the study area varies widely primarily because of the wide range in altitudes and resultant orographic effects. Annual precipitation values can vary from $30 \mathrm{in}$. at higher altitudes to $6 \mathrm{in}$. or less in the valley floors. Annual runoff generally mimics the precipitation with greater quantities occurring at higher altitudes than those at lower altitudes.

Streamflows vary greatly on a seasonal basis; the bulk of the annual runoff occurs as snowmelt in spring (April, May, and June). In late fall and winter streamflows generally are smaller than in spring and are provided almost entirely by ground-water discharge.

\section{Streamflow Data Used}

Monthly streamflow statistics were computed from daily data at six streamflow-gaging stations within the study area (fig. 1, table 1). Continuous streamflow data for central Nevada for water years 1951-2000 were used in the analyses. Each continuous-record station had to have at least 5 years of record through water year 2000, to be included in the study, although some stations did not have a complete record for all months. The period of record for all stations did not necessarily overlap. Data from streamflow-gaging stations were excluded from the analyses if flows were substantially regulated or if flows were affected substantially by large diversions. Ephemeral streams also were not included in the analyses. The monthly mean streamflows computed for each station were published in Hendricks (1963), USGS (1962-2000, published annually), and McKinley and Oliver (1994, 1995).

Partial-record data were collected by the USGS in cooperation with the USFS from April through October for water years 1997-2000 at four basins (fig. 1, table 2) within the study area. A series of 19 single streamflow measurements were made at each of the four sites along with concurrent-streamflow measurements at nearby hydrologically similar continuous-record sites. These measurement data were published in USGS (1997-2000, published annually).

\section{METHODS FOR ESTIMATING MONTHLY STREAMFLOW-DURATION CHARACTERISTICS AT UNGAGED AND PARTIAL-RECORD SITES}

Equations from regression analysis cannot be used directly to estimate unique historical streamflows at ungaged sites. However, certain statistical streamflow-duration characteristics can be estimated for ungaged sites by extending streamflow records from gaged sites to sites with selected similar basin physical and climatic characteristics. Alternatively, concurrentstreamflow measurements at partial-record sites and nearby continuous-record sites (with known duration characteristics) can be used to estimate streamflowduration characteristics at the partial-record site. These methods are used by Parrett and Cartier (1990) and by Riggs (1972, 1973).

Using the basin-characteristics method and a statistical analysis of available monthly data, duration curves of monthly mean streamflows were constructed for each of the six gaged sites. Monthly mean streamflow is defined as the average daily streamflow for any given month averaged over the month. At each gaged site, monthly mean streamflows with exceedence values of $1,5,10,25,50,75,90,95$, and 99 percent (table 3 ) were regressed against certain basin physical and climatic characteristics (table 4) for all months. In addition, streamflows with exceedence values of 5, 25, 50, 75, and 95 percent were regressed against certain basin physical and climatic characteristics for percent exceedence values for each month of the year. 


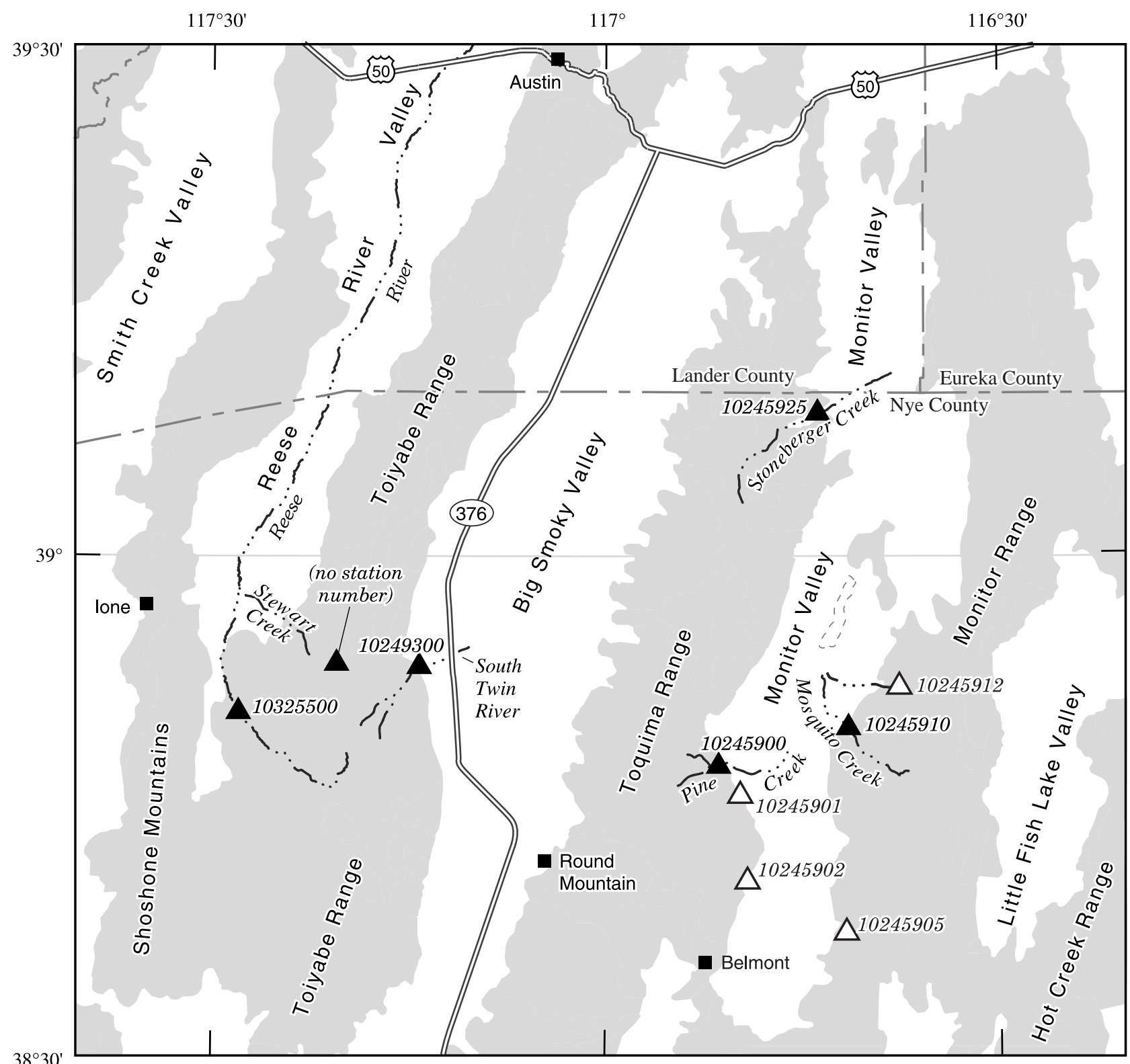

Base from U.S. Geological Survey digital data, 1:100,000, 1987 Lambert Conformal Conic projection

Standard parallels $33^{\circ}$ and $45^{\circ}$, central meridian $-117^{\circ}$

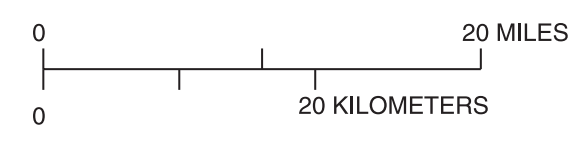

EXPLANATION

\section{Basin fill \\ Consolidated rock \\ 10245900 Streamflow site and station number \\ $10245912 \triangle$ Ungaged streamflow site and station number}

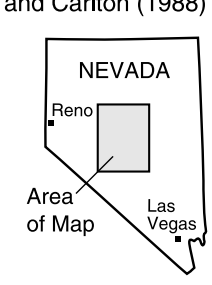

Figure 1. Location of streamflow site and station number in central Nevada. 
Table 1. Mean monthly streamflow of drainage basins in central Nevada

[Symbol: —, no assigned station number]

\begin{tabular}{|c|c|c|c|c|c|c|c|c|c|c|c|c|c|c|}
\hline \multirow{2}{*}{$\begin{array}{l}\text { Station } \\
\text { number } \\
\text { (fig. 1) }\end{array}$} & \multirow{2}{*}{ Station name } & \multirow{2}{*}{$\begin{array}{c}\text { Period of } \\
\text { statistics } \\
\text { (water year) }\end{array}$} & \multicolumn{12}{|c|}{ Mean monthly streamflow (cubic feet per second) } \\
\hline & & & Oct. & Nov. & Dec. & Jan. & Feb. & Mar. & Apr. & May & Jun. & Jul. & Aug. & Sep. \\
\hline 10245900 & Pine Creek near Belmont & 1978-2000 & 2.27 & 1.85 & 1.52 & 1.35 & 1.26 & 1.63 & 3.13 & 16.6 & 24.2 & 7.99 & 3.62 & 2.35 \\
\hline 10245910 & Mosquito Creek near Belmont & $1978-2000$ & .80 & .74 & 60 & .54 & .52 & .68 & 1.54 & 6.44 & 10.9 & 3.28 & 1.25 & .80 \\
\hline 10245925 & Stoneberger Creek near Belmont & 1978-1997 & .56 & .55 & .52 & .49 & .53 & .67 & 1.28 & 5.15 & 6.59 & 2.05 & 1.05 & .66 \\
\hline 10249300 & South Twin River near Round Mountain & $1965-2000$ & 2.47 & 2.65 & 2.46 & 2.38 & 2.59 & 4.75 & 9.23 & 25.2 & 19.5 & 6.37 & 2.94 & 2.26 \\
\hline 10325500 & Reese River near Ione & $1951-1980$ & 2.70 & 2.56 & 2.50 & 2.51 & 3.25 & 5.75 & 23.3 & 48.2 & 29.9 & 8.81 & 3.86 & 2.69 \\
\hline- & East Stewart Creek near Ione & 1987-1991 & .20 & .17 & .15 & .11 & .08 & .09 & .18 & .69 & 1.35 & .53 & .30 & .19 \\
\hline
\end{tabular}

Table 2. Mean monthly streamflow determined at concurrent partial-record sites in central Nevada, water years 1997-2000

[Symbol: —, no measurements made during month]

\begin{tabular}{|c|c|c|c|c|c|c|c|c|c|c|c|c|c|}
\hline \multirow{3}{*}{$\begin{array}{l}\text { Station } \\
\text { number } \\
\text { (fig. 1) }\end{array}$} & \multirow{3}{*}{ Station name } & \multicolumn{12}{|c|}{ Mean monthly streamflow from concurrent-measurement data (cubic feet per second) } \\
\hline & & \multicolumn{12}{|c|}{ Month (number of streamflow measurements) } \\
\hline & & $\begin{array}{l}\text { Oct. } \\
\text { ( 2) }\end{array}$ & $\begin{array}{l}\text { Nov. } \\
(0)\end{array}$ & $\begin{array}{l}\text { Dec. } \\
(0)\end{array}$ & $\begin{array}{l}\text { Jan. } \\
(0)\end{array}$ & $\begin{array}{l}\text { Feb. } \\
(0)\end{array}$ & $\begin{array}{l}\text { Mar. } \\
(0)\end{array}$ & $\begin{array}{c}\text { April } \\
(2)\end{array}$ & $\begin{array}{l}\text { May } \\
(3)\end{array}$ & $\begin{array}{c}\text { June } \\
(4)\end{array}$ & $\begin{array}{l}\text { July } \\
\text { (3) }\end{array}$ & $\begin{array}{l}\text { Aug. } \\
\text { (1) }\end{array}$ & $\begin{array}{c}\text { Sep. } \\
\text { (4) }\end{array}$ \\
\hline 10245901 & Andrews Creek near Belmont & 0.12 & - & - & - & - & - & 1.26 & 1.33 & 3.68 & 1.17 & 0 & 0.24 \\
\hline 10245902 & Corcoran Creek near Belmont & .45 & - & - & - & - & - & .39 & .49 & .61 & .50 & .24 & .41 \\
\hline 10245905 & Barley Creek near Belmont & .79 & - & - & - & - & - & 8.3 & 23.7 & 26.6 & 3.38 & 0 & 1.21 \\
\hline 10245912 & Morgan Creek near Belmont & .26 & - & - & - & - & - & .38 & 1.61 & 1.62 & .82 & .10 & .26 \\
\hline
\end{tabular}


Table 3. Monthly streamflow-duration characteristics of streams at continuous-record sites in central Nevada

[Symbol: —, no assigned station number]

\begin{tabular}{|c|c|c|c|c|c|c|c|c|c|c|}
\hline \multirow{2}{*}{$\begin{array}{l}\text { Station } \\
\text { number }\end{array}$} & \multirow{2}{*}{ Station name } & \multicolumn{9}{|c|}{$\begin{array}{l}\text { Monthly streamflow equalled or exceeded for indicated percentage of time } \\
\text { (cubic feet per second) }\end{array}$} \\
\hline & & 1 & 5 & 10 & 25 & 50 & 75 & 90 & 95 & 99 \\
\hline 10245900 & Pine Creek near Belmont & 61.0 & 21.7 & 16.2 & 4.43 & 1.93 & 1.37 & 1.10 & 1.02 & 0.83 \\
\hline 10245910 & Mosquito Creek near Belmont & 17.3 & 9.36 & 4.24 & 1.71 & .78 & .49 & .33 & .27 & .16 \\
\hline 10245925 & Stoneberger Creek near Belmont & 24.4 & 6.33 & 3.05 & 1.26 & .45 & .24 & .18 & .15 & .10 \\
\hline 10249300 & South Twin River near Round Mountain & 57.5 & 25.5 & 14.5 & 6.38 & 2.90 & 1.99 & 1.49 & 1.25 & .92 \\
\hline 10325500 & Reese River near Ione & 139 & 60.0 & 33.6 & 9.56 & 3.86 & 2.42 & 1.53 & 1.20 & .59 \\
\hline- & East Stewart Creek near Ione & 2.04 & 1.22 & .87 & .38 & .20 & .12 & .08 & .07 & .05 \\
\hline
\end{tabular}

Table 4. Selected physical and climatic characteristics of selected drainage basins in central Nevada

[Symbol: —, no assigned station number]

\begin{tabular}{|c|c|c|c|c|c|c|c|c|c|c|c|c|c|}
\hline $\begin{array}{l}\text { Station } \\
\text { number }\end{array}$ & Station name & $\begin{array}{l}\text { Latitude } \\
\text { (decimal } \\
\text { degrees) }\end{array}$ & $\begin{array}{l}\text { Longitude } \\
\text { (decimal } \\
\text { degrees) }\end{array}$ & $\begin{array}{l}\text { Period of } \\
\text { record } \\
\text { (water } \\
\text { year) }\end{array}$ & $\begin{array}{c}\text { Drainage } \\
\text { area } \\
\text { (square } \\
\text { miles) }\end{array}$ & $\begin{array}{c}\text { Gage } \\
\text { altitude } \\
\text { (feet above } \\
\text { sea level) }\end{array}$ & $\begin{array}{c}\text { Main } \\
\text { channel } \\
\text { slope (feet } \\
\text { per mile) }\end{array}$ & $\begin{array}{c}\text { Mean basin } \\
\text { altitude } \\
\text { (feet above } \\
\text { sea level) }\end{array}$ & $\begin{array}{l}\text { Stream } \\
\text { length } \\
\text { (miles) }\end{array}$ & $\begin{array}{c}\text { Annual } \\
\text { precipitation } \\
\text { (inches) }\end{array}$ & $\begin{array}{c}\text { West- or } \\
\text { east- } \\
\text { facing } \\
\text { basin }\end{array}$ & $\begin{array}{l}\text { Percentage } \\
\text { of basin } \\
\text { above } \\
8,000 \text { feet }\end{array}$ & $\begin{array}{c}\text { Percentage } \\
\text { of basin } \\
\text { above } \\
10,000 \text { feet }\end{array}$ \\
\hline 10245900 & $\begin{array}{l}\text { Pine Creek near } \\
\text { Belmont }\end{array}$ & 38.80 & 116.85 & $1978-2000$ & 12.2 & 7,560 & 720 & 9,842 & 5.00 & 21.9 & east & 98.4 & 47.5 \\
\hline 10245910 & $\begin{array}{c}\text { Mosquito Creek } \\
\text { near Belmont }\end{array}$ & 38.80 & 116.70 & 1978-2000 & 15.1 & 7,200 & 447 & 9,415 & 7.85 & 17.3 & west & 95.4 & 24.5 \\
\hline 10245925 & $\begin{array}{l}\text { Stoneberger Creek } \\
\text { near Belmont }\end{array}$ & 39.14 & 116.60 & 1978-1997 & 35.6 & 6,880 & 204 & 8,415 & 12.55 & 16.9 & east & 73.0 & .2 \\
\hline 10249300 & $\begin{array}{l}\text { South Twin River } \\
\text { near Round } \\
\text { Mountain }\end{array}$ & 38.88 & 117.24 & $1965-2000$ & 20.0 & 6,400 & 604 & 8,985 & 8.10 & 19.3 & east & 84.5 & 12.0 \\
\hline 10325500 & $\begin{array}{l}\text { Reese River near } \\
\text { Ione }\end{array}$ & 38.85 & 117.47 & $1951-1980$ & 53.0 & 7,100 & 180 & 8,768 & 13.45 & 17.2 & west & 80.6 & 10.8 \\
\hline - & $\begin{array}{l}\text { East Stewart Creek } \\
\text { near Ione }\end{array}$ & 38.89 & 117.36 & 1987-1992 & .36 & 9,455 & 1,590 & 10,170 & .85 & 25.2 & west & 100 & 66.7 \\
\hline
\end{tabular}


Historical monthly streamflows could be grossly estimated as follows: (1) use the regression equations in this report to build a streamflow-duration curve for the ungaged site; (2) for each month, determine the percent exceedence for observed streamflow at the nearby gaged index site; and (3) from the streamflow-duration curve for the ungaged site, select the streamflow data corresponding to the same percentile as that experienced at the gaged site for the month of interest.

Basin characteristics at each of the six streamflow gaging-station sites were extracted from USGS topographic maps. Total drainage area was determined by delineating and planimetering basin boundaries on 1:24,000-scale topographic maps. Mean annual precipitation was the basin average precipitation as determined from digital maps (G.H. Taylor, Oregon Climate Service, Oregon State University, written commun., May 1997) using geographic information system (GIS) methods. In a similar manner, mean basin altitude was determined by GIS methods using elevation data from a 1-degree digital elevation model (U.S. Geological Survey, 1995), digitally overlaying a transparent grid on the basin outline, determining the value at the grid intersections, and then averaging the readings. These methods of determining mean annual precipitation and mean basin altitude are different than those used in Hess and Bohman (1996), who used paper topographic maps and manual methods. The stream length was determined by measuring the distance in miles along the main channel from the gaging station to the basin divide. The gage altitude was determined from a topographic map. The channel slope was measured between points, which are 10 percent and 85 percent of the main stream length upstream from the gaging station. A qualitative variable indicating whether a drainage basin is on the east- or west-facing slope of a mountain range also was included in the analyses to determine if a rainshadow effect was discernible. The basin physical and climatic characteristics for the East Stewart Creek site were used from the previous study.

Drainage basin physical and climatic characteristics associated with each streamflow gaging station used in the regression analysis are listed in table 4. More accurate determinations of basin physical and climatic characteristics could have been determined with greater accuracy using other GIS databases. Their use was beyond the scope of this study.
Monthly streamflow data and basin physical and climatic characteristics at the six gaged sites in the study area were transformed to logarithms and used in a multiple-regression analysis to derive estimating equations of the form:

$$
\log \mathrm{Q}_{\mathrm{XX}}=\log \mathrm{a}+\mathrm{b} \log \mathrm{A}+\mathrm{c} \log \mathrm{B}
$$

Commonly expressed as:

$$
\mathrm{Q}_{\mathrm{xx}}=\mathrm{a} \mathrm{A}^{\mathrm{b}} \mathrm{B}^{\mathrm{c}}
$$

where:

$\mathrm{Q}_{\mathrm{xx}}$ is the monthly mean streamflow with an

exceedence probability of $\mathrm{xx}$, in percent;

$\mathrm{A}$ and $\mathrm{B}$ are basin physical and climatic characteristics; and

$\mathrm{a}, \mathrm{b}$, and $\mathrm{c}$ are regression coefficients.

Monthly mean streamflows for each exceedence level were related to the basin physical and climatic characteristics using a stepwise regression procedure (SAS Institute, 1995, p. 440). This procedure adds independent variables to the equation, one at a time, until all statistically significant variables have been included.

The results of the regression analyses indicate that total drainage area and percent of drainage area above a $10,000 \mathrm{ft}$ altitude are the most significant variables for estimating monthly streamflow-duration characteristics for ungaged streams in central Nevada. The procedure also provided statistical measures of the reliability of the derived equations such as the coefficient of determination from regression $\left(\mathrm{R}^{2}\right)$ and the standard error of estimate (SEE). The equations and statistical results are listed in table 5 for the monthly mean streamflows (for all months) of various exceedence levels and in table 6 for the monthly mean streamflows of various exceedence levels and for the monthly mean streamflow (for specific months).

In a study by Parrett and Cartier (1990) in western Montana, $\mathrm{R}^{2}$ and SEE for the equations representing specific months, ranged from 0.57 to 0.87 and from 43 to 107 percent, respectively. Averages not available in Parrett and Cartier. In the study area, Hess and Bohman (1996) reported that for all months the $\mathrm{R}^{2}$ for equations ranged from 0.73 to 0.92 (average 0.85 ) and the SEE ranged from 51 to 96 percent (average 69 percent); and for specific months the $\mathrm{R}^{2}$ for equations ranged from 0.33 to 0.97 (average 0.83 ) and the SEE ranged from 31 to 168 percent (average 74 percent). 
Table 5. Equations derived from basin-characteristics method for estimating monthly mean streamflow-duration characteristics for all months at ungaged sites in central Nevada

$\left[Q_{x x}\right.$, monthly streamflow exceeded $x x$ percent of the time during any month, in cubic feet per second; A, drainage area, in square miles; E10, percentage of basin at altitudes greater than 10,000 feet; $R^{2}$, coefficient of determination from regression analysis; SEE, standard error of estimate]

\begin{tabular}{ccccc}
\hline $\begin{array}{c}\text { Regression equation used to estimate } \\
\text { monthly streamflow-duration characteristic }\end{array}$ & $\mathbf{R}^{2}$ & $\begin{array}{c}\text { SEE } \\
\text { (percent) }\end{array}$ \\
\hline $\mathrm{Q}_{1}$ & $=1.48 \mathrm{~A}^{0.913} \mathrm{E} 10^{0.279}$ & 0.90 & 66 \\
$\mathrm{Q}_{5}$ & $=$ & $0.550 \mathrm{~A}^{0.872} \mathrm{E} 10^{0.374}$ & .92 & 54 \\
$\mathrm{Q}_{10}$ & $=0.317 \mathrm{~A}^{0.833} \mathrm{E} 10^{0.414}$ & .86 & 73 \\
$\mathrm{Q}_{25}$ & $=0.170 \mathrm{~A}^{0.744} \mathrm{E} 10^{0.349}$ & .85 & 65 \\
$\mathrm{Q}_{50}$ & $=0.074 \mathrm{~A}^{0.708} \mathrm{E} 10^{0.385}$ & .84 & 65 \\
$\mathrm{Q}_{75}$ & $=0.038 \mathrm{~A}^{0.743} \mathrm{E} 10^{0.436}$ & .84 & 70 \\
$\mathrm{Q}_{90}$ & $=0.027 \mathrm{~A}^{0.746} \mathrm{E} 10^{0.429}$ & .82 & 75 \\
$\mathrm{Q}_{95}$ & $=0.023 \mathrm{~A}^{0.732} \mathrm{E} 10^{0.433}$ & .81 & 78 \\
$\mathrm{Q}_{99}$ & $=0.018 \mathrm{~A}^{0.686} \mathrm{E} 10^{0.427}$ & .73 & 99 \\
\hline
\end{tabular}

In this study, the $\mathrm{R}^{2}$ and the SEE for the relations are comparable to those ranges. For the regression equations that include all months, the $\mathrm{R}^{2}$ ranged from 0.73 to 0.92 (average 0.84 ), and the SEE of the relations ranged from 54 to 99 percent (average 72 percent; table $5)$. For the specific monthly relations, the $R^{2}$ ranged from 0.10 to 0.94 (average 0.72 ), and the SEE ranged from 36 to 237 percent (average 78 percent; table 6). The accuracy of both types of regression equations developed in this study generally is comparable to those in the previous study by Hess and Bohman (1996). This study had a slight increase in SEE probably because of a wetter period of record (1995-2000) used and a wider range in streamflow values. This range in streamflow values would tend to cause a wider variation in the statistical computations. This example shows that additional data collection does not necessarily ensure a more reliable regression relation, though it may lessen the need for extrapolation and therefore be more robust.

Using the concurrent-measurement method, measured streamflow at four partial-record sites were correlated with concurrent streamflow at nearby gaged sites with continuous records. The relation between the streamflow at the gaged and partial-record sites can then be used to extend the desired long-term streamflow characteristic at the gaged site to the partial-record site. This method was used to estimate monthly streamflows in Montana in Parrett and Cartier (1990). According to Searcy (1959, p. 17) and Riggs (1972, p. 15), the concurrent-measurement method generally provides more reliable estimates of low-streamflow characteristics than other methods in which streamflow measurements are not used.

The concurrent-measurement method using measurements for the period of April to October was applied at selected partial-record sites. Because the 19 monthly measurements were collected from April to October (an average of less than 3 measurements for each month), data are too few to develop a monthly relation for each streamflow-duration characteristic. Because the 19 monthly measurements were collected at partial-record sites, the data are not continuous and, therefore, monthly streamflow-duration relations can not be developed. However, relations for all months combined were developed and are listed in table 5.

To determine this relation, the 19 measurements at each partial-record site were paired with concurrent daily mean streamflow obtained from a similar, nearby continuous-record site. A correlation matrix was used to determine the strength of individual relations between the six continuous-record and four partialrecord sites. The correlation matrix indicated which of the six continuous-record sites were statistically the best indicator, or index station, for streamflow at the four partial-record sites. Measurements at the index station were then paired with concurrent measurements made at the partial-record site. Using simple linearregression techniques, a straight line was fitted through the data points. Parrett and Cartier (1990) used a more elaborate curve-fitting technique at 20 partial-record sites using 12 monthly streamflow measurements. However, for this central Nevada study, only simple linear-regression techniques were used because of the limited amount of data from four sites.

For each partial-record site, the accuracy of the regression relation was examined by comparing observed streamflow to the streamflow determined from the linear regression for the four pairs as listed in table 7. As in the first method, the $\mathrm{R}^{2}$ was determined for each relation. These values ranged from 0.39 to 0.89 (average 0.72). The SEE was determined by comparing each of the observations for the four sites. The SEE 
Table 6. Equations derived from basin-characteristics method for estimating monthly streamflow-duration characteristics for individual months at ungaged sites in central Nevada

$\left[\mathrm{Q}_{\mathrm{xx}}\right.$, monthly mean discharge exceeded xx percent of the time during the specified month, in cubic feet per second; $\mathrm{Q}_{\text {mean }}$, mean monthly discharge, in cubic feet per second; A, drainage area, in square miles; E10, percentage of basin at altitudes greater than 10,000 feet; $\mathrm{R}^{2}$, coefficient of determination from regression]

\begin{tabular}{|c|c|c|c|c|c|c|c|c|c|c|c|}
\hline \multirow{2}{*}{$\begin{array}{l}\text { Month } \\
\text { Oct. }\end{array}$} & \multicolumn{3}{|c|}{$\begin{array}{l}\text { Regression equation for indicated } \\
\text { streamflow characteristic }\end{array}$} & $\begin{array}{c}\mathbf{R}^{2} \\
0.82\end{array}$ & $\begin{array}{c}\begin{array}{c}\text { Standard } \\
\text { error of } \\
\text { estimate } \\
\text { (percent) }\end{array} \\
55\end{array}$ & $\begin{array}{l}\text { Month } \\
\text { April }\end{array}$ & \multicolumn{3}{|c|}{$\begin{array}{l}\text { Regression equation for indicated } \\
\text { streamflow characteristic }\end{array}$} & $\begin{array}{c}\mathbf{R}^{2} \\
0.75\end{array}$ & $\begin{array}{c}\begin{array}{c}\text { Standard } \\
\text { error of } \\
\text { estimate } \\
\text { (percent) }\end{array} \\
121\end{array}$ \\
\hline & $\begin{array}{l}\mathrm{Q}_{5} \\
\mathrm{Q}_{25} \\
\mathrm{Q}_{50} \\
\mathrm{Q}_{75} \\
\mathrm{Q}_{95} \\
\mathrm{Q}_{\text {mean }}\end{array}$ & $\begin{array}{l}= \\
= \\
= \\
= \\
= \\
=\end{array}$ & $\begin{array}{l}0.18 \mathrm{~A}^{0.75} \mathrm{E} 10^{0.24} \\
0.10 \mathrm{~A}^{0.72} \mathrm{E} 10^{0.36} \\
0.06 \mathrm{~A}^{0.67} \mathrm{E} 10^{0.42} \\
0.05 \mathrm{~A}^{0.63} \mathrm{E} 10^{0.46} \\
0.04 \mathrm{~A}^{0.55} \mathrm{E} 10^{0.48} \\
0.13 \mathrm{~A}^{0.56} \mathrm{E} 10^{0.14}\end{array}$ & $\begin{array}{r}0.82 \\
.85 \\
.74 \\
.71 \\
.51 \\
.35\end{array}$ & $\begin{array}{r}55 \\
46 \\
61 \\
65 \\
90 \\
108\end{array}$ & April & $\begin{array}{l}\mathrm{Q}_{5} \\
\mathrm{Q}_{25} \\
\mathrm{Q}_{50} \\
\mathrm{Q}_{75} \\
\mathrm{Q}_{95} \\
\mathrm{Q}_{\text {mean }}\end{array}$ & $\begin{array}{l}= \\
= \\
= \\
= \\
= \\
=\end{array}$ & $\begin{array}{l}0.17 \mathrm{~A}^{1.13} \mathrm{E} 10^{0.30} \\
0.12 \mathrm{~A}^{0.97} \mathrm{E} 10^{0.36} \\
0.07 \mathrm{~A}^{0.97} \mathrm{E} 10^{0.40} \\
0.03 \mathrm{~A}^{0.98} \mathrm{E} 10^{0.59} \\
0.02 \mathrm{~A}^{0.97} \mathrm{E} 10^{0.55} \\
0.08 \mathrm{~A}^{1.05} \mathrm{E} 10^{0.32}\end{array}$ & $\begin{array}{r}0.75 \\
.66 \\
.72 \\
.75 \\
.74 \\
.81\end{array}$ & $\begin{array}{r}121 \\
123 \\
100 \\
96 \\
95 \\
77\end{array}$ \\
\hline Nov. & $\begin{array}{l}\mathrm{Q}_{5} \\
\mathrm{Q}_{25} \\
\mathrm{Q}_{50} \\
\mathrm{Q}_{75} \\
\mathrm{Q}_{95} \\
\mathrm{Q}_{\text {mean }}\end{array}$ & $\begin{array}{l}= \\
= \\
= \\
= \\
= \\
=\end{array}$ & $\begin{array}{l}0.19 \mathrm{~A}^{0.73} \mathrm{E} 10^{0.20} \\
0.11 \mathrm{~A}^{0.71} \mathrm{E} 10^{0.31} \\
0.06 \mathrm{~A}^{0.69} \mathrm{E} 10^{0.41} \\
0.04 \mathrm{~A}^{0.66} \mathrm{E} 10^{0.44} \\
0.03 \mathrm{~A}^{0.62} \mathrm{E} 10^{0.50} \\
0.09 \mathrm{~A}^{0.67} \mathrm{E} 10^{0.31}\end{array}$ & $\begin{array}{l}.81 \\
.79 \\
.73 \\
.70 \\
.74 \\
.74\end{array}$ & $\begin{array}{l}56 \\
55 \\
65 \\
68 \\
62 \\
59\end{array}$ & May & $\begin{array}{l}\mathrm{Q}_{5} \\
\mathrm{Q}_{25} \\
\mathrm{Q}_{50} \\
\mathrm{Q}_{75} \\
\mathrm{Q}_{95} \\
\mathrm{Q}_{\text {mean }}\end{array}$ & $\begin{array}{l}= \\
= \\
= \\
= \\
= \\
=\end{array}$ & $\begin{array}{l}1.39 \mathrm{~A}^{0.99} \mathrm{E} 10^{0.18} \\
1.43 \mathrm{~A}^{0.86} \mathrm{E} 10^{0.10} \\
0.18 \mathrm{~A}^{0.95} \mathrm{E} 10^{0.51} \\
0.03 \mathrm{~A}^{1.02} \mathrm{E} 10^{0.83} \\
0.03 \mathrm{~A}^{0.94} \mathrm{E} 10^{0.72} \\
0.19 \mathrm{~A}^{1.06} \mathrm{E} 10^{0.41}\end{array}$ & $\begin{array}{l}.89 \\
.87 \\
.82 \\
.82 \\
.77 \\
.81\end{array}$ & $\begin{array}{l}59 \\
59 \\
72 \\
88 \\
91 \\
82\end{array}$ \\
\hline Dec. & $\begin{array}{l}\mathrm{Q}_{5} \\
\mathrm{Q}_{25} \\
\mathrm{Q}_{50} \\
\mathrm{Q}_{75} \\
\mathrm{Q}_{95} \\
\mathrm{Q}_{\text {mean }}\end{array}$ & $\begin{array}{l}= \\
= \\
= \\
= \\
= \\
=\end{array}$ & $\begin{array}{l}0.19 \mathrm{~A}^{0.69} \mathrm{E} 10^{0.15} \\
0.09 \mathrm{~A}^{0.70} \mathrm{E} 10^{0.29} \\
0.05 \mathrm{~A}^{0.70} \mathrm{E} 10^{0.42} \\
0.04 \mathrm{~A}^{0.69} \mathrm{E} 10^{0.40} \\
0.03 \mathrm{~A}^{0.60} \mathrm{E} 10^{0.41} \\
0.08 \mathrm{~A}^{0.67} \mathrm{E} 10^{0.29}\end{array}$ & $\begin{array}{l}.81 \\
.76 \\
.72 \\
.66 \\
.43 \\
.71\end{array}$ & $\begin{array}{r}54 \\
61 \\
67 \\
75 \\
105 \\
65\end{array}$ & June & $\begin{array}{l}\mathrm{Q}_{5} \\
\mathrm{Q}_{25} \\
\mathrm{Q}_{50} \\
\mathrm{Q}_{75} \\
\mathrm{Q}_{95} \\
\mathrm{Q}_{\text {mean }}\end{array}$ & $\begin{array}{l}= \\
= \\
= \\
= \\
= \\
=\end{array}$ & $\begin{array}{l}2.65 \mathrm{~A}^{0.89} \mathrm{E} 10^{0.17} \\
0.86 \mathrm{~A}^{0.74} \mathrm{E} 10^{0.34} \\
0.28 \mathrm{~A}^{0.77} \mathrm{E} 10^{0.52} \\
0.13 \mathrm{~A}^{0.69} \mathrm{E} 10^{0.59} \\
0.06 \mathrm{~A}^{0.63} \mathrm{E} 10^{0.77} \\
0.34 \mathrm{~A}^{0.90} \mathrm{E} 10^{0.42}\end{array}$ & $\begin{array}{l}.94 \\
.84 \\
.71 \\
.77 \\
.88 \\
.87\end{array}$ & $\begin{array}{l}36 \\
50 \\
79 \\
66 \\
53 \\
55\end{array}$ \\
\hline Jan. & $\begin{array}{l}\mathrm{Q}_{5} \\
\mathrm{Q}_{25} \\
\mathrm{Q}_{50} \\
\mathrm{Q}_{75} \\
\mathrm{Q}_{95} \\
\mathrm{Q}_{\text {mean }}\end{array}$ & $\begin{array}{l}= \\
= \\
= \\
= \\
= \\
=\end{array}$ & $\begin{array}{l}0.14 \mathrm{~A}^{0.75} \mathrm{E} 10^{0.18} \\
0.09 \mathrm{~A}^{0.73} \mathrm{E} 10^{0.26} \\
0.04 \mathrm{~A}^{0.75} \mathrm{E} 10^{0.41} \\
0.03 \mathrm{~A}^{0.75} \mathrm{E} 10^{0.39} \\
0.03 \mathrm{~A}^{0.65} \mathrm{E} 10^{0.38} \\
0.06 \mathrm{~A}^{0.73} \mathrm{E} 10^{0.30}\end{array}$ & $\begin{array}{l}.74 \\
.79 \\
.72 \\
.66 \\
.54 \\
.73\end{array}$ & $\begin{array}{l}74 \\
58 \\
72 \\
83 \\
91 \\
68\end{array}$ & July & $\begin{array}{l}\mathrm{Q}_{5} \\
\mathrm{Q}_{25} \\
\mathrm{Q}_{50} \\
\mathrm{Q}_{75} \\
\mathrm{Q}_{95} \\
\mathrm{Q}_{\text {mean }}\end{array}$ & $\begin{array}{l}= \\
= \\
= \\
= \\
= \\
=\end{array}$ & $\begin{array}{l}0.11 \mathrm{~A}^{0.80} \mathrm{E} 10^{0.22} \\
0.32 \mathrm{~A}^{0.69} \mathrm{E} 10^{0.35} \\
0.13 \mathrm{~A}^{0.71} \mathrm{E} 10^{0.44} \\
0.11 \mathrm{~A}^{0.58} \mathrm{E} 10^{0.43} \\
0.07 \mathrm{~A}^{0.44} \mathrm{E} 10^{0.51} \\
0.24 \mathrm{~A}^{0.70} \mathrm{E} 10^{0.29}\end{array}$ & $\begin{array}{l}.69 \\
.87 \\
.82 \\
.69 \\
.73 \\
.81\end{array}$ & $\begin{array}{l}88 \\
40 \\
52 \\
61 \\
55 \\
50\end{array}$ \\
\hline Feb. & $\begin{array}{l}\mathrm{Q}_{5} \\
\mathrm{Q}_{25} \\
\mathrm{Q}_{50} \\
\mathrm{Q}_{75} \\
\mathrm{Q}_{95} \\
\mathrm{Q}_{\text {mean }}\end{array}$ & $\begin{array}{l}= \\
= \\
= \\
= \\
= \\
=\end{array}$ & $\begin{array}{l}0.11 \mathrm{~A}^{0.85} \mathrm{E} 10^{0.19} \\
0.07 \mathrm{~A}^{0.80} \mathrm{E} 10^{0.25} \\
0.04 \mathrm{~A}^{0.85} \mathrm{E} 10^{0.37} \\
0.03 \mathrm{~A}^{0.83} \mathrm{E} 10^{0.40} \\
0.02 \mathrm{~A}^{0.80} \mathrm{E} 10^{0.38} \\
0.05 \mathrm{~A}^{0.83} \mathrm{E} 10^{0.30}\end{array}$ & $\begin{array}{l}.75 \\
.81 \\
.76 \\
.70 \\
.67 \\
.76\end{array}$ & $\begin{array}{l}82 \\
61 \\
76 \\
88 \\
89 \\
74\end{array}$ & Aug. & $\begin{array}{l}\mathrm{Q}_{5} \\
\mathrm{Q}_{25} \\
\mathrm{Q}_{50} \\
\mathrm{Q}_{75} \\
\mathrm{Q}_{95} \\
\mathrm{Q}_{\text {mean }}\end{array}$ & $\begin{array}{l}= \\
= \\
= \\
= \\
= \\
=\end{array}$ & $\begin{array}{l}0.41 \mathrm{~A}^{0.76} \mathrm{E} 10^{0.20} \\
0.16 \mathrm{~A}^{0.68} \mathrm{E} 10^{0.35} \\
0.12 \mathrm{~A}^{0.62} \mathrm{E} 10^{0.33} \\
0.07 \mathrm{~A}^{0.51} \mathrm{E} 10^{0.39} \\
0.11 \mathrm{~A}^{0.22} \mathrm{E} 10^{0.29} \\
0.12 \mathrm{~A}^{0.40} \mathrm{E} 10^{0.11}\end{array}$ & $\begin{array}{l}.85 \\
.87 \\
.72 \\
.61 \\
.10 \\
.21\end{array}$ & $\begin{array}{r}52 \\
39 \\
58 \\
64 \\
101 \\
171\end{array}$ \\
\hline Mar. & $\begin{array}{l}\mathrm{Q}_{5} \\
\mathrm{Q}_{25} \\
\mathrm{Q}_{50} \\
\mathrm{Q}_{75} \\
\mathrm{Q}_{95} \\
\mathrm{Q}_{\text {mean }}\end{array}$ & $\begin{array}{l}= \\
= \\
= \\
= \\
= \\
=\end{array}$ & $\begin{array}{l}0.09 \mathrm{~A}^{1.03} \mathrm{E} 10^{0.26} \\
0.06 \mathrm{~A}^{1.00} \mathrm{E} 10^{0.30} \\
0.03 \mathrm{~A}^{0.98} \mathrm{E} 10^{0.44} \\
0.02 \mathrm{~A}^{0.93} \mathrm{E} 10^{0.46} \\
0.02 \mathrm{~A}^{0.88} \mathrm{E} 10^{0.45} \\
0.05 \mathrm{~A}^{0.93} \mathrm{E} 10^{0.34}\end{array}$ & $\begin{array}{l}.69 \\
.76 \\
.74 \\
.75 \\
.65 \\
.72\end{array}$ & $\begin{array}{r}128 \\
97 \\
95 \\
88 \\
106 \\
97\end{array}$ & Sept. & $\begin{array}{l}\mathrm{Q}_{5} \\
\mathrm{Q}_{25} \\
\mathrm{Q}_{50} \\
\mathrm{Q}_{75} \\
\mathrm{Q}_{95} \\
\mathrm{Q}_{\text {mean }}\end{array}$ & $\begin{array}{l}= \\
= \\
= \\
= \\
= \\
=\end{array}$ & $\begin{array}{l}0.27 \mathrm{~A}^{0.73} \mathrm{E} 10^{0.20} \\
0.12 \mathrm{~A}^{0.67} \mathrm{E} 10^{0.33} \\
0.07 \mathrm{~A}^{0.60} \mathrm{E} 10^{0.39} \\
0.05 \mathrm{~A}^{0.56} \mathrm{E} 10^{0.45} \\
0.05 \mathrm{~A}^{0.43} \mathrm{E} 10^{0.44} \\
0.13 \mathrm{~A}^{0.60} \mathrm{E} 10^{0.16}\end{array}$ & $\begin{array}{l}.86 \\
.80 \\
.66 \\
.60 \\
.38 \\
.58\end{array}$ & $\begin{array}{r}237 \\
50 \\
66 \\
74 \\
96 \\
72\end{array}$ \\
\hline
\end{tabular}


Table 7. Equations derived from concurrent-measurement method for estimating monthly streamflow for all months at partial-record sites in central Nevada using streamflow at nearby gaging stations

$\left[Q_{x x}\right.$, streamflow at site, in cubic feet per second; $R^{2}$, coefficient of determination from regression analysis. Abbreviation: SEE, standard error of estimate]

\begin{tabular}{llrc}
\hline $\begin{array}{c}\text { Regression equation used to estimate } \\
\text { monthly streamflow-duration characteristic }\end{array}$ & $\mathbf{R}^{\mathbf{2}}$ & $\begin{array}{c}\text { SEE } \\
\text { (percent) }\end{array}$ \\
\hline $\mathrm{Q}_{\text {Andrews }}=$ & $0.141 \mathrm{Q}_{\text {Pine }}+0.01$ & 0.89 & 76 \\
$\mathrm{Q}_{\text {Barley }}=\quad 1.94 \mathrm{Q}_{\text {Mosquito }}+0.1$ & .76 & 1,023 \\
$\mathrm{Q}_{\text {Corcoran }}=$ & $0.020 \mathrm{Q}_{\text {Mosquito }}+0.3$ & .39 & 14 \\
$\mathrm{Q}_{\text {Morgan }}=0.319 \mathrm{Q}_{\text {Mosquito }}+0.01$ & .86 & 37 \\
$\mathrm{Q}_{\text {Andrews }}=0.141 \mathrm{Q}_{\text {Pine }}+0.01$ & .89 & 76 \\
\hline
\end{tabular}

varied from 14 percent (Corcoran Creek), 37 percent (Morgan Creek), 76 percent (Andrews Creek) to 1,023 percent (Barley Creek). Barley Creek has a wider variation in streamflows ( 0 to $89 \mathrm{ft}^{3} / \mathrm{s}$ ) than the other concurrent sites which could be the reason for the higher SEE. Using the other three sites, the average SEE is 42 percent. As a comparison, in the Parrett and Cartier (1990) study, the standard error ranged from 19 to 92 percent using this technique.

Comparison of the average SEE for the concurrent-measurement method (42 percent) with the average SEE for the basin-characteristics method (72 percent) indicates that the concurrent-measurement method typically is more reliable than the other method for estimating monthly streamflows for any month of the year. A similar comparison of $\mathrm{R}^{2}(0.72$ and 0.84 , respectively) indicates the same conclusion.

\section{RELIABILITY AND LIMITATIONS OF ESTIMATING METHODS}

The statistical reliability of many of the equations is poor because only six observations (continuousrecord sites) were available for the analyses. These limited observations did not allow proper definition of the true relation of each independent variable to the dependent variable in most equations. More observations generally would improve the reliability of regression equations.

The regression equations determined in the basin characteristics method may not be applicable beyond the range of values (table 4) used to derive the equations. Extrapolation beyond the values listed in tables 5 and 6 may yield estimates with greater errors than those indicated.

The equations presented in this report are valid only for: (1) streams in the study area; (2) streams on the mountain block areas; (3) perennial streams; and (4) streams with insignificant diversions and regulation upstream of the site of interest. The equations are not valid for: (1) streams in the valleys or on alluvial fans; (2) streams in areas with fractured consolidated bedrock that tend to lose surface water streamflow to ground-water; and (3) estimating historical streamflows resulting from summertime convective storms which may have been caused by localized runoff in isolated parts of the study area.

Even though the concurrent-measurement method typically is more accurate than the basin-characteristics method, the concurrent-measurement method requires additional streamflow data collection at partial-record sites for several years. As applied to this study, the concurrent-measurement method cannot be used for estimating monthly streamflow-duration characteristics for individual months due to an inadequate number of monthly streamflow measurements.

Snowmelt is the primary source of water for streamflow in central Nevada during certain times of the year. Snowmelt induced streamflows may vary diurnally by as much as 100 percent. Streamflow measurements were made at the continuous- and partialrecord sites during the same day, but never at the same time during the day. Diurnal variations, thus, may introduce an error into concurrent-measurement method calculations during periods of snowmelt.

\section{APPLICATIONS}

General procedures for making estimates of monthly streamflows using methods described herein are illustrated in the following examples:

Example 1: An estimate of the monthly streamflow rate exceeded 50 percent of the time $\left(\mathrm{Q}_{50}\right)$ for July is required for an ungaged site in the study area. The following basin characteristics were measured from a topographic map:

$$
\text { Drainage Area }(\mathrm{A})=10 \mathrm{mi}^{2}=\mathrm{A}
$$

Percentage of basin above 10,000 ft elevation $(\mathrm{E} 10)=$

$$
25.0=\mathrm{B}
$$


Monthly streamflow-duration characteristics for 50 percent exceedence $\left(\mathrm{Q}_{50}\right.$; table 5) is calculated as follows:

$$
\begin{aligned}
& \mathrm{Q}_{50}=0.074 \mathrm{~A}^{0.708} \mathrm{E} 10^{0.385} \\
& \mathrm{Q}_{50}=0.074(10)^{0.708}(25.0)^{0.385} \\
& \mathrm{Q}_{50}=1.30 \mathrm{ft}^{3} / \mathrm{s}
\end{aligned}
$$

Values of $\mathrm{Q}_{1}$ to $\mathrm{Q}_{99}$ are calculated from the equations listed in table 5. Streamflow-duration data from the index station, Mosquito Creek near Belmont, are plotted on arithmetic probability paper (fig. 2) with the values of $\mathrm{Q}_{1}$ to $\mathrm{Q}_{99}$. The monthly mean streamflow of Mosquito Creek for July is $3.28 \mathrm{ft}^{3} / \mathrm{s}$ (table 1). Examination of the streamflow-duration curve for Mosquito Creek shows that the $3.28 \mathrm{ft}^{3} / \mathrm{s}$ value is exceeded 14 percent of the time. Returning to the streamflow-duration curve for the ungaged site determined from table 5 , the streamflow associated with the percentage of time exceeded is 14 percent is $6.0 \mathrm{ft}^{3} / \mathrm{s}$. Thus, the monthly mean streamflow for July at the ungaged site is 6.0 $\mathrm{ft}^{3} / \mathrm{s}$.

Example 2: Estimates of the monthly mean streamflow for July is required for an ungaged site in the study area. The following basin characteristics were measured from a topographic map:
Drainage Area $(\mathrm{A})=10 \mathrm{mi}^{2}=\mathrm{A}$

Percentage of basin above $10,000 \mathrm{ft}$ elevation $(\mathrm{E} 10)=$

$$
25.0=\mathrm{B}
$$

Monthly mean streamflow is determined by calculating $\mathrm{Q}_{\text {mean }}$ (table 6) as follows:

$$
\begin{aligned}
& \mathrm{Q}_{\text {mean }}=0.24 \mathrm{~A}^{0.70} \mathrm{E} 10^{0.29} \\
& \mathrm{Q}_{\text {mean }}=0.24(10)^{0.70}(25.0)^{0.29} \\
& \mathrm{Q}_{\text {mean }}=3.1 \mathrm{ft}^{3} / \mathrm{s}
\end{aligned}
$$

Thus, the monthly mean streamflow for July at the ungaged site is $3.1 \mathrm{ft}^{3} / \mathrm{s}$.

Example 3: An estimate of the streamflow at Andrews Creek for the monthly $Q_{95}$ is needed. By use of the relation between Pine Creek (continuous-record index station) and Andrews Creek (partial-record site with concurrent measurements) applicable equations from table 7 , the monthly streamflow-duration characteristic for $\mathrm{Q}_{95}$ Pine Creek from table 3 is $1.02 \mathrm{ft}^{3} / \mathrm{s}$. For example, $Q_{95}$ Andrews is calculated as follows:

$$
\begin{aligned}
& \mathrm{Q}_{95 \text { Andrews }}=0.141\left(\mathrm{Q}_{95 \text { Pine Creek }}\right)+0.01 \\
& \mathrm{Q}_{95 \text { Andrews }}=0.141(1.02)+0.01 \\
& \mathrm{Q}_{95 \text { Andrews }}=0.15 \mathrm{ft}^{3} / \mathrm{s}
\end{aligned}
$$

Thus, the monthly streamflow for Andrews Creek $\mathrm{Q}_{95}$ is $0.15 \mathrm{ft}^{3} / \mathrm{s}$.

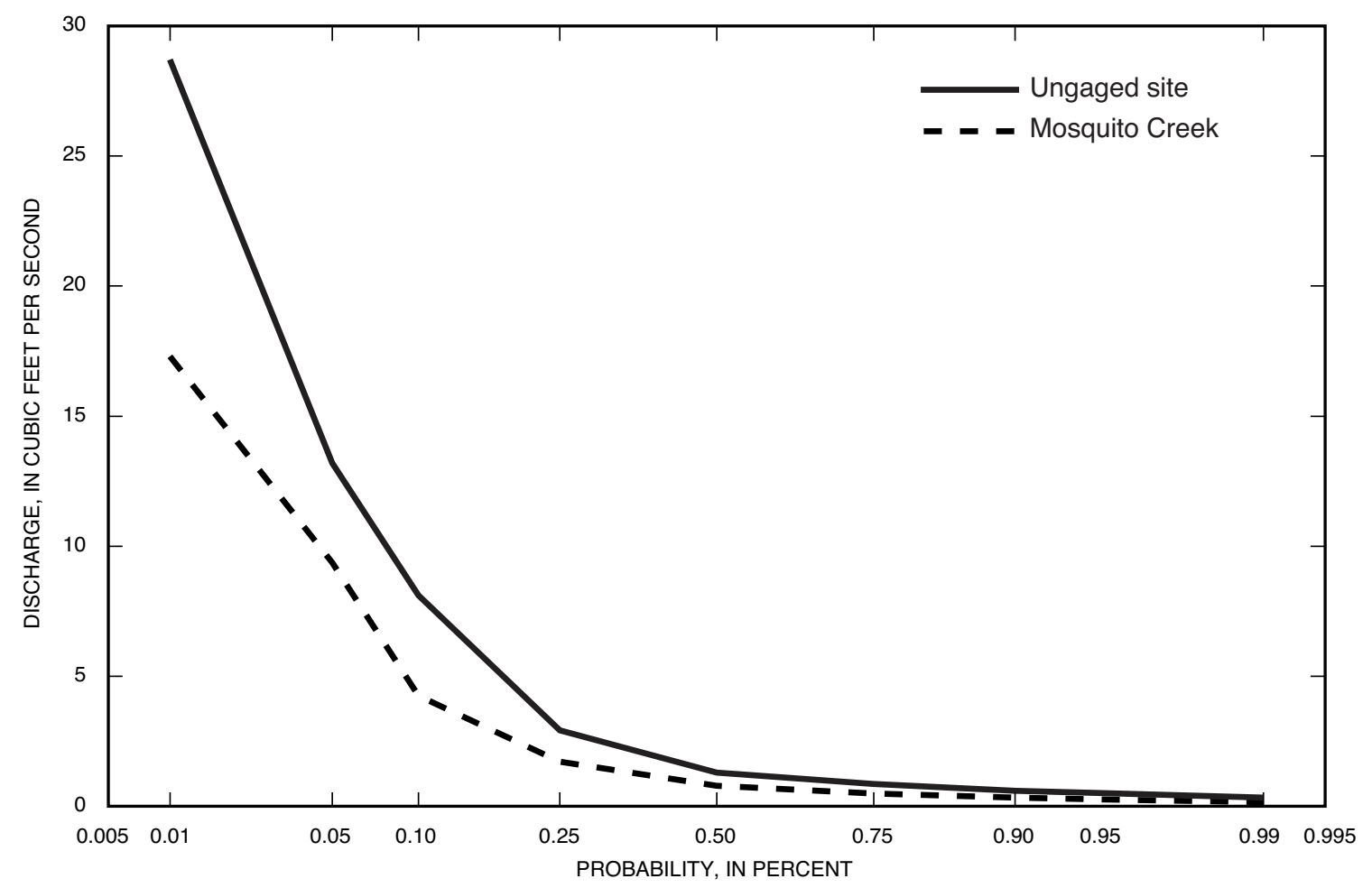

Figure 2. Probability of streamflow-duration data from the index station, Mosquito Creek near Belmont, used in example 1 application. 


\section{SUMMARY}

Two methods, the basin-characteristic method and the concurrent-measurement method, were developed to update estimating techniques for selected streamflow characteristics at ungaged and partialrecord sites in central Nevada. Gaged streamflow data were available from six sites within the study area and streamflow measurements were available for 4 years at partial-record sites with concurrent measurements.

In the first method, basin-characteristics method, streamflow data at gaged sites were related to basin physical and climatic characteristics by regression techniques. Total drainage area, percent of drainage area above 8,000 and $10,000 \mathrm{ft}$, channel slope, stream length, gage altitude, mean basin altitude, and mean annual precipitation were determined for each basin. Monthly streamflow data for selected percent exceedence levels were used in regression analyses with basin physical and climatic variables to determine relations for ungaged basins. Analyses indicate that the total drainage area and percent of drainage area at altitudes above $10,000 \mathrm{ft}$ are the most significant variables. For equations in which all months of the year were combined, the $\mathrm{R}^{2}$ averaged 0.84 and the SEE of the relations averaged 72 percent. For equations representing individual months of the year, the $\mathrm{R}^{2}$ averaged 0.72 and the SEE of the relations averaged 78 percent. The statistics for both the combined and individual monthly regression equations indicate that the updated relations are slightly less accurate than those developed in a previous study. This difference is probably the result of additional streamflow data collected during wetter periods (1995-2000) used in the current study, which has a wider range in streamflow values.

In the second method, concurrent-measurement method, streamflow measurements at partial-record sites were correlated with concurrent streamflows at nearby continuous-record sites by the use of linearregression techniques. Statistical measures typically were more reliable than for the first method. However, the concurrent-measurement method requires additional streamflow data collection at partial-record sites to develop relations for individual months.

\section{REFERENCES CITED}

Hendricks, E.L., 1963, Compilation of records of surface waters, October 1950 to September 1960, Part 10. The Great Basin: U.S. Geological Survey Water-Supply Paper 1734, $318 \mathrm{p}$.

Hess, G.W., 1999, Hydrologic data for water years 1978-97 used in daily flow-routing and river-operations models for the Upper Carson River basin, California and Nevada: U.S. Geological Survey Open-File Report 99-256, 16 p.

2002, Simulation of streamflow, Middle Humboldt River, north-central Nevada: U.S. Geological Survey Water-Resources Investigations Report 01-4231, 34 p.

Hess, G.W., and Bohman, L.R., 1996, Techniques for estimating monthly mean streamflow at gaged sites and monthly streamflow duration characteristics at ungaged sites in central Nevada: U.S. Geological Survey OpenFile Report 96-559, 15 p.

Maurer, D.K., 1986, Geohydrology and simulated response to ground-water pumpage in Carson Valley, a riverdominated basin in Douglas County, Nevada, and Alpine County, California: U.S. Geological Survey Water-Resources Investigations Report 86-4328, 109 p.

McKinley, P.W., and Oliver, T.A., 1994, Meteorological, stream discharge and water quality data for 1986 through 1991 from two small basins in central Nevada: U.S. Geological Survey Open-File Report 93-651, $167 \mathrm{p}$.

1995, Meteorological, stream discharge and water quality data for water year 1992 from two basins in central Nevada: U.S. Geological Survey Open-File Report 94-456, $56 \mathrm{p}$.

Moore, D.O., 1968, Estimating mean runoff in ungaged semiarid areas: Nevada Department of Conservation and Natural Resources, Water Resources Bulletin no. 36, p. 29-39.

Myers, T.J., and Swanson, S., 1996, Long-term aquatic habitat restoration-Mahogany Creek Nevada, as a case study: Water Resources Bulletin, v. 32, no. 2, p. 241-252.

Parrett, C., and Cartier, K.D., 1990, Methods for estimating monthly streamflow characteristics at ungaged sites in western Montana: U.S. Geological Survey WaterSupply Paper 2365, 30 p.

Plume, R.W., and Carlton, S.M., 1988, Hydrogeology of the Great Basin region of Nevada, Utah and adjacent states: U.S. Geological Survey Hydrologic Investigation Atlas HA-694-A, 1 sheet, scale 1:1,000,000. 
Riggs, H.C., 1972, Low-flow investigations: U.S. Geological Survey Techniques of Water-Resources Investigations, book 4, chap. B1, $18 \mathrm{p}$.

1973, Regional analyses of Streamflow characteristics: U.S. Geological Survey Techniques of WaterResources Investigations, book 4, chap. B3, 15 p.

SAS Institute, Inc., 1995, Basic statistics using SAS/STAT software: SAS Institute, $720 \mathrm{p}$.
Searcy, J.K., 1959, Flow-duration curves, in Manual of hydrology, part 2, Low-flow techniques: U.S. Geological Survey Water-Supply Paper 1542-A, 33 p.

U.S. Geological Survey, 1962-00, Water resources data, Nevada, water years 1962-00: U.S. Geological Survey Water-Data Reports NV-62 to NV-00-1 (published annually). 
Since 1879, the U.S. Geological Survey has been providing maps, reports, and information to help others who manage, develop, and protect our Nation's water, energy, mineral, land, and biological resources. We help find natural resources, and we supply scientific understanding needed to help minimize or mitigate the effects of natural hazards and the environmental damage caused by human activities. The results of our efforts touch the daily lives of almost everyone. 